\title{
Isolation and Identification of a Cellulase-producing Bacillus sp. Strain BR0302 from Thai Coastal Wetland Soil
}

\author{
Aiya Chantarasiri*, Parima Boontanom, Nattawut Yensaysuk and Puwanat Ajwichai \\ Faculty of Science, Energy and Environment, King Mongkut's University of Technology North Bangkok, Rayong \\ Campus, Rayong, Thailand \\ * Corresponding author. E-mail: aiya.c@sciee.kmutnb.ac.th \\ Received: 11 June 2015; Accepted: 6 July 2015; Published online: 24 July 2015 \\ (C) 2015 King Mongkut's University of Technology North Bangkok. All Rights Reserved.
}

\begin{abstract}
This study proposed the isolation, screening and identification of cellulase-producing bacteria from Thai coastal wetland soil. Eighty seven bacterial strains which demonstrated cellulase-producing bacteria were investigated for cellulolytic properties. The bacterium identified as Bacillus cereus strain BR0302 exhibited the highest hydrolysis activity on carboxymethylcellulose agar plates. Cellulolytic performance for CMCase activity and FPase activity was $0.121 \pm 0.006$ and $0.057 \pm 0.001 \mathrm{U} / \mathrm{mL}$ respectively. Cellulolytic characteristics showed that the B. cereus strain BR0302 could be used for the hydrolysis of cellulosic biomass for biofuel production.
\end{abstract}

Keywords: Bacillus cereus, Cellulase-producing bacteria, Coastal wetland soil

\section{Introduction}

Biotechnological conversion of cellulosic biomass is a sustainable approach to create glucose and reducing sugars for the production of bioethanol and other biofuels. Cellulolytic enzymes have currently become focal biocatalysts in biotechnological conversion applications [1]; they are produced by numerous microorganisms for the depolymerization of cellulose in cellulosic materials. These complex enzymes include endoglucanases (E.C. 3.2.1.4), exoglucanases (E.C. 3.2.1.91, E.C. 3.2.1.176) and $\beta$-glucosidases (E.C. 3.2.1.21) which work together to hydrolyse the $\beta-1,4$ glycosidic bonds of cellulose [2]. Most cellulolytic enzymes are produced from fungi, such as the genera Trichoderma and Aspergillus, and bacteria including the genera Bacillus, Clostridium and Cellulomonas [3], [4]. The bacterial cellulolytic enzyme is often a more effective catalyst because it has short fermentation cycle time, low-cost energy utilization and it is easy to genetically engineer [4], [5]. One major impediment for cellulosic biofuels is the lack of microorganisms which can produce sufficient cellulolytic enzymes to breakdown the cellulose [6].

Coastal wetlands are unique ecosystems with complex interactions between terrestrial, marine and aquatic habitats [7], [8]. They are crucial ecosystems for study and research because of their ecological roles, which include the storage of surface runoff, nutrient cycling, sediment accretion, pollution filtration, shoreline erosion control and the habitats of many shoreline animals [7], [9]. The microbial communities in coastal wetland soil and sediments play a vital role in wetland ecological functions [9]. These include nitrogen and phosphorus transformation processes and organic matter degradation [10]. However, studies on microbial communities, including cellulolytic microbes isolated from coastal wetland soil, are very limited because of frequent flooding conditions resulting in low rates of degradation and low microbial activity [11], [12].

For this study, the cellulase-producing bacterium strain BR0302 was isolated from coastal wetland

Please cite this article as: A. Chantarasiri, P. Boontanom, N. Yensaysuk, and P. Ajwichai, "Isolation and Identification of a Cellulase-producing Bacillus sp. Strain BR0302 from Thai Coastal Wetland Soil," KMUTNB Int J Appl Sci Technol, Vol. 8, No. 3, pp. 197-203, July-Sept. 2015, http://dx.doi.org/10.14416/j.ijast.2015.07.002 
soil and identified by morphology and $16 \mathrm{~S}$ rDNA sequencing analysis. The purpose was to determine a cellulase-producing bacterium for possible use in biotechnological conversion.

\section{Materials and Methods}

\subsection{Chemicals, culture media and microorganism}

The chemicals used in this study were of analytical grade, purchased from Sigma-Aldrich (MO, USA), Calbiochem (Darmstadt, Germany) and Merck(Darmstadt, Germany). Culture media were purchased from HiMedia (Mumbai, India). Bacillus methylotrophicus strain RYC01101 [13] and Escherichia coli isolated from bovine faeces were kindly provided by the Faculty of Science, Energy and Environment, King Mongkut's University of Technology North Bangkok. Salmonella sp. was obtained from the Department of Microbiology, Faculty of Science, Mahidol University, Bangkok.

\subsection{Site description, sample collection and isolation of bacteria}

Sample collection methods and isolation of bacteria were modified from Chantarasiri et al [13]. Soil samples were collected from Bueng Samnak Yai (Nong Chamrung) coastal wetland $\left(12^{\circ} 39^{\prime} 39^{\prime \prime} \mathrm{N}\right.$, $\left.101^{\circ} 32^{\prime} 09^{\prime \prime} \mathrm{E}\right)$ in Rayong Botanical Garden, Rayong Province, Thailand. Bueng Samnak Yai coastal wetland consists of five shoals: Koh-Kok, Koh-Taeo Yai, Koh-Cha Muang, Koh-Taeo Lek and Koh-Mai Nham (Figure 1). The main plants included Melaleuca quinquenervia (Thai name: Samed Khao), Garcinia cowa (Cha Muang), Cratoxylum formosum (Taeo) and Lepironia articulata (Kok Krajood). Bueng Samnak Yai coastal wetland was designated as a National Wetland Reserve in 2009. Soil samples were collected during the period from July 2014 to August 2014 (rainy season). The soil samples were collected twice, one in late July and another in late August. Soil samples from soil surface and at a depth of $15 \mathrm{~cm}$ were taken in steriled zip-lock polyethylene bags using steriled spatula. The soil samples were kept at $4{ }^{\circ} \mathrm{C}$ and serially diluted with steriled ultrapure water within $24 \mathrm{~h}$ of collection to obtain 1:1,000 dilutions. One hundred microlitres of each diluted sample was cultured in nutrient agar and incubated at $29.2^{\circ} \mathrm{C}$, the average

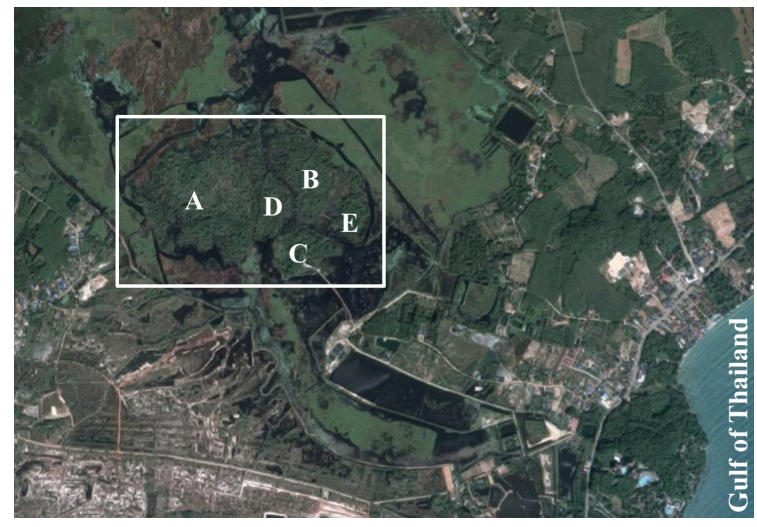

Figure 1: Map of five shoals in Bueng Samnak Yai coastal wetland: (A) Koh-Kok, (B) Koh-Taeo Yai, (C) Koh-Cha Muang, (D) Koh-Taeo Lek and (E) Koh-Mai Nham, covering an area of 130 hectares.

soil temperature of the collecting sites, for $48 \mathrm{~h}$. Morphologically dissimilar colonies of bacteria were picked and streak plated on nutrient agar to obtain pure colonies.

\subsection{Screening of cellulase-producing bacteria}

Screening of the cellulase-producing bacteria was done on carboxymethylcellulose (CMC) agar plates, following the method of Kasana et al [14]. Five microlitres of overnight growth culture in the nutrient broth of each bacterial isolate was spot plated on CMC agar $(0.2 \%$ $\mathrm{NaNO}_{3}, 0.1 \% \mathrm{~K}_{2} \mathrm{HPO}_{4}, 0.05 \% \mathrm{MgSO}_{4}, 0.05 \% \mathrm{KCl}$, $0.2 \% \mathrm{CMC}$ sodium salt, $0.02 \%$ peptone and $1.7 \%$ agar). The plates were incubated at $29.2^{\circ} \mathrm{C}$ for $48 \mathrm{~h}$ and then flooded with Gram's iodine solution $(0.67 \% \mathrm{KI}$ and $0.33 \% \mathrm{I}_{2}$ ) for $5 \mathrm{~min}$. The cellulase-producing isolates were detected by the cellulolytic zone around the colonies after Gram's iodine staining. The hydrolysis capacity (HC) was calculated from the ratio between the diameter of the cellulolytic zone and the diameter of the bacterial colony [13]. The cellulase-producing isolates were further screened by measuring the amount of reducing sugars hydrolyzed from the substrates in the culture medium. The isolates were grown in $10 \mathrm{~mL}$ of CMC broth at $29.2^{\circ} \mathrm{C}$ under aeration condition. After $48 \mathrm{~h}$ of incubation, $1 \mathrm{~mL}$ of culture medium was collected for reducing sugar measurement by the DNS method [15]. The cell-free culture medium was added by $3.0 \mathrm{~mL}$ of 3,5-dinitrosalicylic acid reagent and then 
immediately boiled for 5 min. Cooled the solution thoroughly and measured the optical density of the solution at $540 \mathrm{~nm}$. The amount of reducing sugars was calculated using glucose standard curve. The positive control for screening was the cellulolytic bacteria, B. methylotrophicus strain RYC01101 and the negative control was E. coli.

\subsection{Estimation of cellulase activity}

To determine the cellulase activity, the selected isolate was grown in $100 \mathrm{~mL}$ of CMC broth at $29.2^{\circ} \mathrm{C}$ for $48 \mathrm{~h}$ under aeration condition. The crude extracellular cellulase produced in the broth was collected by centrifugation at $4,500 \times \mathrm{g}$ for $30 \mathrm{~min}$ at $4^{\circ} \mathrm{C}$. The cell-free supernatant obtained after centrifugation served as crude cellulase source. The cellulase activity was assayed by incubating the crude cellulase solution with the substrate and estimating the amount of reducing sugars released from the substrate. One unit (U) is defined as the quantity of cellulase activity required to release $1 \mu \mathrm{mol}$ of reducing sugars as glucose equivalent under standard assay conditions [13]. Endoglucanase activity (CMCase activity) [16] was determined by incubating $0.5 \mathrm{~mL}$ of crude cellulase solution with $0.5 \mathrm{~mL}$ of $2 \%$ CMC sodium salt in $0.05 \mathrm{M}$ sodium citrate buffer $(\mathrm{pH}$ $4.8)$ at $50^{\circ} \mathrm{C}$ for $30 \mathrm{~min}$. The enzyme reaction was terminated by adding $3.0 \mathrm{~mL}$ of 3,5-dinitrosalicylic acid reagent and then immediately boiled for $5 \mathrm{~min}$. The quantity of reducing sugars liberated from the CMC was determined by the DNS method [15]. Total cellulase activity (FPase activity) [17] was measured by incubating $0.5 \mathrm{~mL}$ of crude cellulase solution, $1.0 \mathrm{~mL}$ of $0.05 \mathrm{M}$ sodium citrate buffer ( $\mathrm{pH} 4.8$ ) and $50 \mathrm{mg}$ of Whatman No. 1 filter paper strip at $50^{\circ} \mathrm{C}$ for $1 \mathrm{~h}$. After incubation, the enzyme reaction was stopped and the amount of reducing sugars liberated from the filter paper strip was measured by the DNS method [15].

\subsection{Identification of cellulase-producing bacteria}

The identification of the selected cellulase-producing isolate was performed by molecular genetics analysis and standard identifications. The PCR amplification and $16 \mathrm{~S}$ rDNA sequence analysis of the selected isolate were performed by the Thailand Institute of Scientific and Technological Research (Pathum Thani, Thailand). The isolate was further characterized by standard identifications such as Gram staining, endospore staining, motility test, catalase test [18] and oxidase test [19]. Identification of facultative anaerobic bacteria was determined as previously described [13]. The isolate was cultured on anaerobic agar at $29.2^{\circ} \mathrm{C}$ for $48 \mathrm{~h}$ under anaerobic condition in an AnaeroJar (Oxiod, England) assembled with an AnaeroGen sachet (Oxiod). Growth under the saline condition was determined by supplementing nutrient agar with $0-30 \%$ (w/v) of $\mathrm{NaCl}$ and incubated at $29.2^{\circ} \mathrm{C}$ for $48 \mathrm{~h}$. For identification of closely related bacteria in the Bacillus genus, microscopic methods and antimicrobial activity were further determined. Antimicrobial activity of the cellulolytic isolates was assayed by the disc diffusion method against Gram-negative bacterial pathogens including E. coli and Salmonella sp. on nutrient agar at $37^{\circ} \mathrm{C}$ for $48 \mathrm{~h}$.

\subsection{Application on the biotechnological conversion}

To produce reducing sugars using the biotechnological conversion process, the cellulosic biomass was hydrolysed by a selected cellulase-producing bacterium. Rice straw, rubber tree leaves and paper waste, agroresidues and municipal waste in Rayong Province, were used as the carbon source of bacterial culture. The selected cellulase-producing bacterium was cultured in a basal medium $\left(0.2 \% \mathrm{NaNO}_{3}, 0.1 \% \mathrm{~K}_{2} \mathrm{HPO}_{4}\right.$, $0.05 \% \mathrm{MgSO}_{4}, 0.05 \% \mathrm{KCl}$ and $0.02 \%$ peptone), supplemented with $1 \%$ cellulosic biomass powder at $29.2^{\circ} \mathrm{C}$ under aeration condition for $48 \mathrm{~h}$. The culture medium was collected for reducing sugars determination by the DNS method [15].

\section{Results and Discussion}

Forty-two soil samples were collected from five shoals in Bueng Samnak Yai coastal wetland. All samples were diluted, spread plated on nutrient agar and incubated under experimental conditions. One hundred and forty-five morphologically dissimilar colonies were isolated and streak plated onto nutrient agar for single colony purification. Eighty-seven isolates exhibited the cellulolytic zone around their colonies after Gram's iodine staining. Hydrolysis capacity values were calculated and a white-pigmented bacterial isolate, strain BR0302, obtained from the Koh-Kok shoal showed a maximum hydrolysis 
capacity of $4.15 \pm 0.18$, greater than the positive control (B. methylotrophicus strain RYC01101) by a factor of 1.34 . In CMC broth, the bacterium strain BR0302 produced the maximum amount of reducing sugars of $0.158 \pm 0.034$ $\mathrm{mg} / \mathrm{mL}$ after $48 \mathrm{~h}$ of incubation (Table 1 and Figure 2).

Table 1: Hydrolysis capacity of bacteria after culture on $\mathrm{CMC}$ agar and amount of reducing sugars after culture in CMC broth at $29.2^{\circ} \mathrm{C}$ for $48 \mathrm{~h}$

\begin{tabular}{|c|c|c|c|}
\hline No. & Bacterial strain & $\begin{array}{c}\text { Hydrolysis } \\
\text { capacity (HC) }\end{array}$ & $\begin{array}{c}\text { Amount of reducing } \\
\text { sugars }(\mathbf{m g} / \mathbf{m L})\end{array}$ \\
\hline 1 & BR0102 & $3.22 \pm 0.08$ & $0.132 \pm 0.007$ \\
\hline 2 & BR0202 & $3.24 \pm 0.14$ & $0.130 \pm 0.002$ \\
\hline 3 & BR0204 & $3.30 \pm 0.05$ & $0.138 \pm 0.003$ \\
\hline 4 & BR0302 & $4.15 \pm 0.18$ & $0.158 \pm 0.034$ \\
\hline 5 & BR0502 & $3.60 \pm 0.14$ & $0.138 \pm 0.002$ \\
\hline 6 & BR0603 & $3.19 \pm 0.20$ & $0.126 \pm 0.008$ \\
\hline 7 & BR0701 & $3.33 \pm 0.06$ & $0.138 \pm 0.006$ \\
\hline 8 & BR0702 & $3.42 \pm 0.15$ & $0.133 \pm 0.017$ \\
\hline 9 & BR0906 & $3.11 \pm 0.19$ & $0.132 \pm 0.005$ \\
\hline 10 & BR1101 & $3.14 \pm 0.18$ & $0.132 \pm 0.007$ \\
\hline 11 & BR1401 & $3.60 \pm 0.29$ & $0.122 \pm 0.005$ \\
\hline 12 & BR1604 & $3.30 \pm 0.14$ & $0.136 \pm 0.005$ \\
\hline 13 & BR1901 & $3.69 \pm 0.05$ & $0.134 \pm 0.002$ \\
\hline 14 & BR2402 & $3.16 \pm 0.10$ & $0.126 \pm 0.002$ \\
\hline 15 & BR2605 & $3.44 \pm 0.20$ & $0.129 \pm 0.007$ \\
\hline 16 & BR2901 & $3.22 \pm 0.51$ & $0.130 \pm 0.002$ \\
\hline 17 & BR3504 & $3.26 \pm 0.05$ & $0.132 \pm 0.001$ \\
\hline 18 & $\begin{array}{c}\text { B. methylotrophicus } \\
\text { strain RYC01101* }\end{array}$ & $3.09 \pm 0.39$ & $0.163 \pm 0.003$ \\
\hline
\end{tabular}

* positive control

Note: The hydrolysis capacity values of any isolates less than the positive control are not shown.

The bacterium strain BR0302 was selected for crude extracellular cellulase production and the cellulase activity was determined. Cellulase activity assays showed that BR0302 yielded $0.121 \pm 0.006 \mathrm{U} / \mathrm{mL}$ of CMCase activity and $0.057 \pm 0.001 \mathrm{U} / \mathrm{mL}$ of FPase activity. Surprisingly, BR0302 showed a maximum hydrolysis capacity but enzyme activity was less than the positive control (Table 1 and 2). Ahmad et al. [20] suggested that this conflicting result may be due to fluctuations in some experimental parameters which affect the enzyme producing processes such as $\mathrm{pH}$ changes in medium, incubation time and incubation temperature. This enzyme activity was compared to other bacteria in the Bacillus genus isolated from soil and oil palm meal (Table 2). The comparisons showed that bacterium strain BR0302 had a moderate cellulase activity.
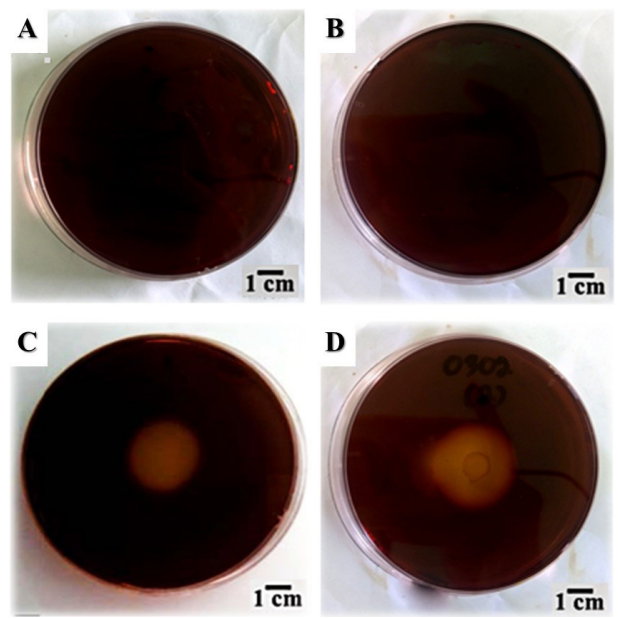

Figure 2: The cellulolytic zone around the colonies on CMC agar plates after Gram's iodine staining. (A) Uninoculated. (B) Inoculated with $E$. coli (negative control). (C) Inoculated with B. methylotrophicus strain RYC01101 (positive control). (D) Inoculated with bacterium strain BR0302.

Table 2: Cellulase activity of bacterium strain BR0302 and related species in the Bacillus genus

\begin{tabular}{|c|c|c|c|c|}
\hline Bacteria & Source & $\begin{array}{c}\text { CMCase } \\
\text { activity } \\
\text { (U/mL) }\end{array}$ & $\begin{array}{c}\text { FPase } \\
\text { activity } \\
\text { (U/mL) }\end{array}$ & Ref. \\
\hline $\begin{array}{c}\text { B. velesensis } \\
\text { strain P3-1 }\end{array}$ & Soil & 0.015 & ND & {$[21]$} \\
\hline $\begin{array}{c}\text { B. velesensis } \\
\text { strain P4-6 }\end{array}$ & Soil & 0.015 & ND & {$[21]$} \\
\hline $\begin{array}{c}\text { B. safensis } \\
\text { strain PJ1-24S }\end{array}$ & $\begin{array}{c}\text { Oil palm } \\
\text { meal }\end{array}$ & 0.233 & ND & {$[22]$} \\
\hline $\begin{array}{c}\text { B. altitudinis } \\
\text { strain PH27 }\end{array}$ & $\begin{array}{c}\text { Oil palm } \\
\text { meal }\end{array}$ & 0.170 & ND & {$[22]$} \\
\hline $\begin{array}{c}\text { B. cereus } \\
\text { strain PH4-36 }\end{array}$ & $\begin{array}{c}\text { Oil palm } \\
\text { meal }\end{array}$ & 0.039 & ND & {$[22]$} \\
\hline $\begin{array}{c}\text { B. methylotrophicus } \\
\text { strain RYC01101* }\end{array}$ & $\begin{array}{c}\text { Bovine } \\
\text { faeces }\end{array}$ & 0.230 & 0.080 & {$[13]$} \\
\hline $\begin{array}{c}\text { Bacterium } \\
\text { strain BR0302 }\end{array}$ & $\begin{array}{c}\text { Coastal } \\
\text { wetland } \\
\text { soil }\end{array}$ & 0.121 & 0.057 & $\begin{array}{c}\text { This } \\
\text { study }\end{array}$ \\
\hline
\end{tabular}

* positive control

ND denotes 'not determined'

Morphology of the bacterium strain BR0302 showed creamy white colonies, flat with entire margin and 5-6 mm in diameter. Bacterial cells were $1 \times 3 \mu \mathrm{m}$, rod-shaped, Gram-positive, endospore-forming and motile. The cells were arranged singly or in short chains. The endospores were round or oval-shaped, located at 


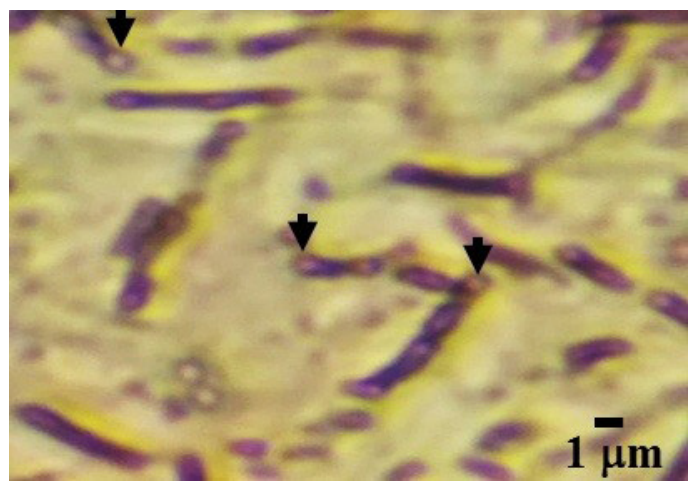

Figure 3: Micrograph of bacterium BR0302 with Gram staining $(\times 400)$, arrows indicate the endospores.

the middle and end of the cells. Cell morphology and arrangement is shown in Figure 3. Catalase and oxidase tests were positive. The bacterium was a facultative anaerobe with a salinity tolerance range of $0-5 \% \mathrm{NaCl}$. The 16S rDNA sequencing analysis showed that the BR0302 strain was identified as a bacterium in the Bacillus genus. It was homologous with $B$. thuringiensis, B. toyonensis and B. cereus with $100 \%$ similarity. The classification of the bacterium strain BR0302 from other closely related species of Bacillus genus required identification by unique characteristics, using microscopic methods and antimicrobial activity.

B. thuringiensis $(\mathrm{Bt})$ is a rod-shaped Gram-positive bacterium which exhibits various biological activities including insecticidal, nematocidal and anticancer activity [23]. Lee et al. reported that $\mathrm{Bt}$ was able to produce unique parasporal crystals after growth on a nutrient agar plate at $30^{\circ} \mathrm{C}$ for 5 days [24]. The bacterium strain BR0302 did not produce the parasporal crystals after 5 days under microscopic investigation. B. toyonensis is a rod-shaped Gram-positive bacterium and its viable spores are used as the active ingredient of the feed additive TOYOCERIN ${ }^{\circledR}$ [25], [26]. TOYOCERIN ${ }^{\circledR}$ has demonstrated inhibition of the growth of pathogenic bacteria such as Salmonella sp. and E. coli. The antimicrobial activity showed that the bacterium strain BR0302 gave a zone of inhibition against Salmonella sp. of $2.0 \mathrm{~mm}$ around the paper discs, but had no antimicrobial activity against $E$. coli. From morphology, 16S rDNA sequencing data and antimicrobial activity analysis, the bacterium strain BR 0302 could be identified as $B$. cereus. For preliminary application on biotechnological conversion, the agro- residues and paper waste were hydrolyzed by $B$. cereus strain BR0302 to produce reducing sugar. After $48 \mathrm{~h}$ of incubation, rice straw, rubber tree leaves and paper waste contained reducing sugars of $0.135 \pm 0.001$, $0.170 \pm 0.000$ and $0.123 \pm 0.004 \mathrm{mg} / \mathrm{mL}$ respectively.

Several strains of Bacillus were reported as cellulase-producing bacteria [27]. The cellulaseproducing $B$. cereus was isolated from oil palm meal, Phetchaburi Province, Thailand [22]. B. cereus strain PH4-39 showed cellulase hydrolysis activity on CMC agar plates by 2.12 after $48 \mathrm{~h}$ of incubation and yielded $0.039 \pm 0.002 \mathrm{U} / \mathrm{mL}$ of CMCase activity. In this study, B. cereus strain BR0302 isolated from coastal wetland soil showed more efficient cellulase activity and could be used in the hydrolysis of cellulosic biomass and agro-residues to produce reducing sugars, the prerequisite of the bioethanol fermentation process. Furthermore, it could be utilized in various industries such as food, textiles and fabrics, laundry detergents, pulp and paper and animal feeds.

\section{Conclusions}

The research of microbes isolated from coastal wetlands has been limited due to frequent flooding conditions. In this study, eighty-seven cellulase-producing bacteria were isolated from coastal wetland soil samples in Rayong Province, Thailand. The bacterium strain BR0302, identified as B. cereus, showed maximum cellulolytic activity compared to other isolated bacteria. The B. cereus strain BR0302 could be used for the biotechnological conversion of agro-residues and municipal waste, to produce glucose and reducing sugars for production of bioethanol and other biofuels.

\section{Acknowledgments}

Aiya Chantarasiri was funded by King Mongkut's University of Technology North Bangkok. Contract no. KMUTNB-GEN-57-53. We are grateful to Rayong Botanical Garden for providing the coastal soil samples.

\section{References}

[1] R.C. Kuhad, R. Gupta, and A. Singh, "Microbial cellulases and their industrial applications," Enzyme Research, 2011, Doi.org/10.4061/2011/ 280696 
[2] V. Juturu and J.C. Wu, "Microbial cellulases: engineering, production and applications," Renew. Sust. Energ Rev., vol. 33, pp. 188-203, 2014.

[3] A. Gupta and J.P. Verma, "Sustainable bioethanol production from agro-residues: a review," Renew. Sust. Energ Rev., vol. 41, pp. 550-567, 2015.

[4] L. Ma, W. Yang, F. Meng, S. Ji, H. Xin, and B. Cao, "Characterization of an acidic cellulase produced by Bacillus subtilis BY-4 isolated from gastrointestinal tract of Tibetan pig," J. Taiwan Inst. Chem. Eng., 2015, Doi:10.1016/j.jtice.2015. 04.025

[5] J. A. Khan, R. K. Ranjan, V. Rathod, and P. Gautam, "Deciphering cow dung for cellulase producing bacteria," Eur. J. Exp. Biol., vol. 1, no. 1, pp. 139-147, 2011.

[6] M. Maki, K.T.Leung, and W. Qin, "The prospects of cellulase-producing bacteria for the bioconversion of lignocellulosic biomass," Int. J. Biol. Sci., vol. 5, pp. 500-516, 2009.

[7] J. M. Ryan and Y. Ntiamoa-Baidu, "Biodiversity and ecology of coastal wetlands in Ghana," Biodivers. Conserv., vol. 9, pp. 445-446, 2000.

[8] Z. Sun, W. Sun, C. Tong, C. Zeng, X. Yu, and X. Mou, "China's coastal wetlands: conservation history, implementation efforts, existing issues and strategies for future improvement," Environ. Int., vol. 79, pp. 25-41, 2015.

[9] Y. Yu, H. Wang, J. Liu, Q. Wang, T. Shen, W. Guo, and R. Wang, "Shifts in microbial community function and structure along the successional gradient of coastal wetlands in Yellow River Estuary," Eur. J. Soil Biol., vol. 49, pp. 12-21, 2012.

[10] M. Truu, J. Juhanson, and J. Truu, "Microbial biomass, activity and community composition in constructed wetlands," Sci. Total Environ., vol. 407, pp. 3958-3971, 2009.

[11] B. Bernal and W.J. Mitsch, "Comparing carbon sequestration in temperate freshwater wetland communities," Glob. Change Biol., vol. 18, pp. 1636-1647, 2012.

[12] Y. Hu, L. Wang, Y. Tang, Y. Li, J. Chen, X. Xi, Y. Zhang, X. Fu, J. Wu, and Y. Sun, "Variability in soil microbial community and activity between coastal and riparian wetlands in the Yangtze River estuary-potential impacts on carbon sequestration," Soil Biol. Biochem., vol. 70, pp. 221-228, 2014.

[13] A. Chantarasiri, "Novel halotolerant cellulolytic Bacillus methylotrophicus RYC01101 isolated from ruminant feces in Thailand and its application for bioethanol production," KMUTNB Int. J. Appl. Sci. Technol., vol. 7, no. 3, pp. 63-68, 2014.

[14] R. C. Kasana, R. Salwan, H. Dhar, S. Dutt, and A. Gulati, "A rapid and easy method for the detection of microbial cellulases on agar plates using Gram's iodine,"Curr. Microbiol., vol. 57, pp. 503-507, 2008.

[15] G. L. Miller, "Use of dinitrosalicylic acid reagent for determination of reducing sugar," Anal. Chem., vol. 31, no. 4, pp. 426-428, 1959.

[16] P. Gupta, K. Samant, and A. Sahu, "Isolation of cellulase-degrading bacteria and determination of their cellulolytic potential," Int. J. Microbiol., 2012, Doi: $10.1155 / 2012 / 578925$

[17] T. K. Ghose, "Measurement of cellulase activity," Pure Appl. Chem., vol. 59, pp. 257-268, 1987.

[18] M. Gagnon, W. Hunting, and W.B. Esselen, "A new method for catalase determination," Anal. Chem., vol. 31, pp. 144, 1959.

[19] J. Gordon and J.W. McLeod, "The practical application of the direct oxidase reaction in bacteriology," J. Pathol. Bacteriol., vol.31, pp. 185190, 1928.

[20] B. Ahmad, S. Nigar, S. Sadaf Ali Shah, S. Bashir, J. Ali, S. Yousaf, and J.A. Bangash, "Isolation and identification of cellulose degrading bacteria from municipal waste and their screening for potential antimicrobial activity," World Appl. Sci. J., vol. 27, no. 11, pp. 1420-1426, 2013.

[21] A. Akaracharanya, T. Taprig, J. Sitdhipol, and S. Tanasupawat, "Characterization of cellulase producing Bacillus and Paenibacillus strains from Thai soils," J. Appl. Pharm. Sci., vol. 4, no. 5, pp. 6-11, 2014.

[22] S. Khianngam, Y. Pootaeng-on, T. Techakriengkrai, and S. Tanasupawat, "Screening and identification of cellulase producing bacteria isolated from oil palm meal," J. Appl. Pharm. Sci., vol. 4, no. 4, pp. 90-96, 2014.

[23] D. W. Lee, T. Akao, S. Yamashita, H. Katayama, M. Maeda, H. Saitoh, E. Mizuki, and M. Ohba, "Noninsecticidal parasporal proteins of a Bacillus thuringiensis serovar shandongiensis isolate exhibit a preferential cytotoxicity against human 
leukemic Tcells," Biochem. Biophys. Res. Commun., vol. 272, pp. 218-223, 2000.

[24] D. W. Lee, Y. H. Je, and Y. H. Koh, "Bacillus thuringiensis isolates from Korean forest environments," J. Asia-Pacific Entomology, vol. 15, pp. 237-239, 2012.

[25] A. Casanovas-Massana, L. Sala-Comorera, and A. R. Blanch, "Quantification of tetracycline and chloramphenicol resistance in digestive tracts of bulls and piglets fed with Toyocerin ${ }^{\circledR}$, a feed additive containing Bacillus toyonensis spores," Vet Microbiol., vol. 173, pp. 59-65, 2014.

[26] G. Jiménez, M. Urdiain, A. Cifuentes, A. López-
López, A. R. Blanch, J. Tamames, P. Kämpfer, A. B. Kolstø, D. Ramón, J. F. Martínez, F. M. Codoñerg, and R. Rosselló-Móra, "Description of Bacillus toyonensis sp. nov., a novel species of the Bacillus cereus group, and pairwise genome comparisons of the species of the group by means of ANI calculations," Syst. Appl. Microbiol., vol. 36, pp. 383-391, 2013.

[27] L. Lin, X. Kan, H. Yan, and D. Wang, "Characterization of extracellular cellulosedegrading enzymes from Bacillus thuringiensis strains," Electron. J. Biotechnol., vol. 15, no. 3, 2012, Doi: 10.2225/vol15-issue3-fulltext-1 